\title{
Control of wood thermal treatment and its effects on decay resistance: a review
}

\author{
Kévin Candelier $^{1}$ • Marie-France Thevenon ${ }^{1}$ • Anélie Petrissans ${ }^{2}$. \\ Stéphane Dumarcay ${ }^{2} \cdot$ Philippe Gerardin $^{2} \cdot$ Mathieu Petrissans $^{2}$
}

Received: 2 June 2015 / Accepted: 27 January 2016/Published online: 24 February 2016

(C) The Author(s) 2016. This article is published with open access at Springerlink.com

\begin{abstract}
- Key message An efficient use of thermal treatment of wood requires a depth understanding of the chemical modifications induced. This is a prerequisite to avoid problems of process control, and to provide high quality treated wood with accurately assessed properties to the market. Properties and structural anatomy of thermally modified woods are slightly different than un-processed woods from a same wood species. So it is necessary to create or adapt new analytical methods to control their quality.

- Context Heat treatment as a wood modification process is based on chemical degradation of wood polymer by heat transfer. It improves mainly the resistance of wood to decay and provides dimensional stability. These improvements, which come at the expense of a weakening of mechanical properties, have been extensively studied. Since a decade, researches focused mainly on the understanding of wood thermal degradation, on modelling, on quality prediction and quality control.
\end{abstract}

Handling Editor: Jean-Michel Leban

Contribution of the co-authors: Kévin Candelier: Corresponding author, review of papers, analysis of reviews, writing the manuscript, supervising preparation of manuscript and finalized the revised papers, according to the comments of all other authors.

Kévin Candelier

kevin.candelier@cirad.fr

Marie-France Thevenon

marie-france.thevenon@cirad.fr

Anélie Petrissans

anelie.petrissans@univ-lorraine.fr

Stéphane Dumarcay

stephane.dumarcay@univ-lorraine.fr
- Aims We aimed at reviewing the recent advances about (i) the analytical methods used to control thermal treatment; (ii) the effects on wood decay resistance and (iii) the advantages and drawbacks of a potential industrial use of wood heating. - Methods We carried out a literature review of the main industrial methods used to evaluate the conferred wood properties, by thermal treatment. We used papers and reports published between 1970 and 2015, identified in the web of science data base.

- Results Approximately 100 papers mostly published after 2000 were retrieved. They concentrated on: (i) wood mass loss due to thermal degradation determination, (ii) spectroscopic analyses of wood properties, (iii) colour measurements, (iv) chemical composition, (v) non-destructive mechanical assessments and (vi) use of industrial data.

- Conclusions One of most interesting property of heat-treated wood remains its decay resistance. Durability test with modified wood in laboratory are expensive and time-consuming. This review displays data from different analytical methods,

Philippe Gerardin

philippe.gerardin@univ-lorraine.fr

Mathieu Petrissans

mathieu.petrissans@univ-lorraine.fr

CIRAD-Unité de Recherches BioWooEB, TA-B 114/ 16 Montpellier, France

2 LERMAB, EA 4370, Faculté des Sciences et Technologies, Université de Lorraine, F-54506 Vandoeuvre-Lès-Nancy, France 
such as spectroscopy, thermogravimetry, chemical analyses or mechanical tests that have the potential to be valuable indicators to assess the durability of heat treated wood at industrial scale. However, each method has its limits and drawbacks, such as the required investment for the equipment, reliability and accuracy of the results and ease of use at industrial scale.

Keywords Heat treatment - Mass loss · Durability . Mechanical resistance $\cdot$ Prediction methods $\cdot$ Quality assessment

\section{Historical overview}

The use of heat treatments to modify the properties of the wood is not recent. Heat-treated wood raised significant research in various countries, for some decades. The first study has been conducted in 1920 Tiemann (1920) on high temperature wood drying process. Results issued from this work have shown that such a process allows mainly to decrease the Equilibrium Moisture Content (EMC) and consequently the wood swelling. In Stamm and Hansen (1937) confirmed these results finding that equilibrium moisture, swelling and shrinkage of wood decreased with heating in several gaseous atmospheres. Then, Stamm et al. (1946) reported a heat treatment to improve wood dimensional stability and resistance to wood-destroying fungi without densification process. None of these modified wood products had much success on the industrial market, probably due to the availability of other high quality timber at the time. Nevertheless, heat treatment was not completely forgotten and several studies were presented later by Seborg et al. (1953), Kollman and Schneider (1963), Kollman and Fengel (1965), Burmester (1973, 1975), Rusche (1973a, 1973b). Shortly after, thermal degradation process had been oriented to produce recoverable energy from lignocellulosic biomasses (Ecoles des Mines de Paris et de Saint Etienne, 1976-77). This material was considered as an energetic resource in between coal and firewood. Thermal Modified Wood (TWM) was studied again as material only since the 80s. After a study involving gas and liquid released during wood thermal degradation, advantageous properties such as wood dimensional stability and decay resistance ameliorations were highlighted (Gieleber 1983; Hillis 1984). The energetic way was then forgotten in favor of the production of a new modified wooden material. More recently there has been a revival interest in heat treatment processes. According to Boonstra (2008) this restored interest is due, to the deforestation of especially sub-tropical forests, the declining production of durable timber, the increasing demand for sustainable building materials and to the increased introduction of governmental restrictive regulations reducing the use of toxic chemicals.
Since the 2000s, studies have been conducted around the world: Netherlands (Boonstra et al. 1996; Tjeerdsma et al. 1998; Militz 2002), Germany (Rapp 2001) and Finland (Kotilainen et al. 2000, Sivonen et al. 2002, Hietala et al. 2002, Nuopponen et al. 2004), leading to set up various industrial processes. All of these industrial processes use sawn timbers and treatment temperatures between $160{ }^{\circ} \mathrm{C}$ and $260{ }^{\circ} \mathrm{C}$, but they differ in terms of process conditions, such as the presence of a shield gas (nitrogen, steam), humid or dryenvironment, conduction or convection heat transfer, use of oils, vacuum or reintroduction of combustion gases (Militz 2002).

\section{Introduction}

Wood modification process has become an attractive way to protect wood material against Moisture Content (MC) variations (Pétrissans et al. 2013) and Basidiomycetes attacks. Heat treatment consists in a wood torrefaction at temperatures ranging from $180^{\circ} \mathrm{C}$ to $250^{\circ} \mathrm{C}$, performed in a very poor oxygen atmosphere to avoid wood combustion. The environmental impact of this process is low, heat is introduced in the treatment system and smokes issued from wood thermal degradation can be retrieved, condensed and purified (Pétrissans et al. 2007). At its end of life cycle, heat-treated wood can be recycled without detrimental impact to the environment to the contrary of chemically treated wood impregnated with biocidal active ingredients (CRIQ 2003). This environmental acceptable treatment improves wood decay resistance (Tjeerdsma et al. 2000) and dimensional stability (Korkut et al. 2012), decreases wood Equilibrium Moisture Content (EMC) (Hill 2006) and induces a darker coloration of wood (Chen et al. 2012), without additional chemical products. Therefore, heat treatment allows to use low durability local timber whose natural durability is low by making them resistant towards decay for a end-use in use class 2 and 3 (use class 4 being excluded due to the occurrence of soft rots) (EN 335 2013) and with high economic value (Allegretti et al. 2012 ; Kamdem et al. 2002). These upgraded properties conferred to the wood are the result of chemical modifications of wood cell wall polymers occurring during treatment (Tjeerdsma and Militz 2005; Yildiz et al. 2006; Inari et al. 2007). However, these durability enhancements have an adverse effect on wood mechanical properties (Gunduz et al. 2009; Andersons et al. 2012; Dilik and Hiziroglu 2012). Although the surface hardness of the heat treated wood is improved, its other mechanical properties, such as bending and compression strengths, stiffness and shear strength, are considerably weakened according to thermal process conditions and treatment intensities (Kocaefe et al. 2008; Candelier et al. 2013d; Hannouz et al. 2015). 
During this last decade several ameliorations on thermal treatment of wood have led to the development of several treatment processes to the European market. The main differences between them lie in the nature of the inert atmosphere and the curing conditions used during the heat treatment: gases (fumes, nitrogen), steam pressure, oil, and recently vacuum (Surini et al. 2012; Allegretti et al. 2012). Earlier works have shown that thermal degradation of wood depends on heat treatment intensity which is directly related to treatment temperature and duration, conditioning thus the final properties of heat treated wood (Rep et al. 2004; Welzbacher et al. 2007). However, even if different studies have been conducted on the effect of treatment intensity (time and temperature) on properties conferred to the material, much less has been reported on the effect of inert atmosphere during the process. Indeed, it is obvious that this parameter impacts directly thermal degradation reactions and consequently the final properties of the material (Candelier et al. 2013a). Thermal degradation reaction mechanisms are different depending on wood specie, treatment intensity and process conditions (Militz 2002; Candelier et al. 2011a). However, some chemical reaction mechanisms occurred during wood thermal degradation still remains unknown according to the modification process used.

Hakkou et al. (2006) and Chaouch et al. (2013) studies, mainly achieved at laboratory scale, have proven good correlations between mass loss issued from wood thermal degradation (ML\%), treatment intensity (time and temperature) and weight loss (WL\%) of heat treated wood due to fungal decay (Hakkou et al. 2005; Chaouch et al. 2013). Because of dehydration reaction occurring during thermal treatment, wood carbon content increases along with treatment intensity whereas oxygen content decreases (Nguila et al. 2009). Elemental wood composition has been reported as a good marker of treatment intensity and, consequently, of mass losses issued from the different degradation reactions allowing further prediction of heat treated wood rot resistance (Šušteršic et al. 2010; Chaouch et al. 2010). However, several authors raised the question of the reliability of heat treated wood durability laboratory tests. According to Junga and Militz (2005), thermal modified wood material is different than untreated wood and it is necessary to adapt different testing methods to evaluate the final durability of this new material. They particularly showed that the EN 113 (1996), usually use as decay resistance test for chemically treated wood, needed some amendments to evaluate the resistance of modified wood towards Basidiomycetes, such as a prolonged test exposure. Kamden et al. (2002) had stated the same conclusions, as they imparted the biological resistance of the heat treated material to its low equilibrium moisture content during a decay test (i.e. the moisture content of the heat treated material is not enough for fungal growth).

Thus, durability tests on modified wood should be carried out over a longer exposure time (i.e. longer than 16 weeks of exposure) so as to overcome a poor estimation of the durability of the new material. These laboratory wood decay resistance tests are destructive, time and money consuming and derivative methods to predict the durability of heat-treated materials are crucially needed. Due to differences of chemical compositions and anatomical structures between untreated and heat treated woods, it is necessary to use other quality characterization methods for modified woods than unprocessed woods.

In addition, most industrial thermal treatment processes use convection heat transfer (Militz 2002) which induces sometimes heterogeneous treatment temperature propagation within the oven (between the periphery and the center of the stack of wooden plates) and lead to the heterogeneity in treatment efficiency (Pétrissans et al. 2007). The wood material variability, wood species and the importance of its initial properties (anatomy, chemical composition, moisture content, etc.) increase these up scaling problems (Willems 2013a; Hamada et al. 2013). Thus, it is common that treatment is not completely effective on several stack boards, in a same batch. Moreover, phenomena of cracking or delamination on the final product can be observed, causing then material and economical losses (Pétrissans et al. 2007). There is a substantial need to understand deeply chemical modifications occurring into the timber during the different heat treatment processes, in order to avoid problems of process control and to insure that the quality of treated timber is properly evaluated with a view to putting this modified timber on the market under a chain of custody.

\section{Wood mass loss (ML \%) due to its thermal degradation}

Mass loss of wood due to its thermal degradation is one of the most important features in heat treatment and it is commonly referred to as an indication of its quality of treatment. Candelier et al. (2013b), Tenorio and Moya (2013) studied mass loss (ML\%) along with heat treatment and concluded that thermal degradation kinetic of wood depends on wood species and process conditions such as drying step, heating medium and treatment intensity (couple temperature duration).

Most of the collected data from literature are difficult to compare because different treatment processes, wood species and their respective initial moisture contents, as well as treatment intensities were used.

Firstly, several authors have shown that wood species and their respective chemical compositions are directly correlated to thermal degradation reaction kinetic. Chaouch (2011) compared the mass losses between hardwood and softwood species, during heat treatment performed by conduction under nitrogen atmosphere. Figure 1 shows that kinetic of 


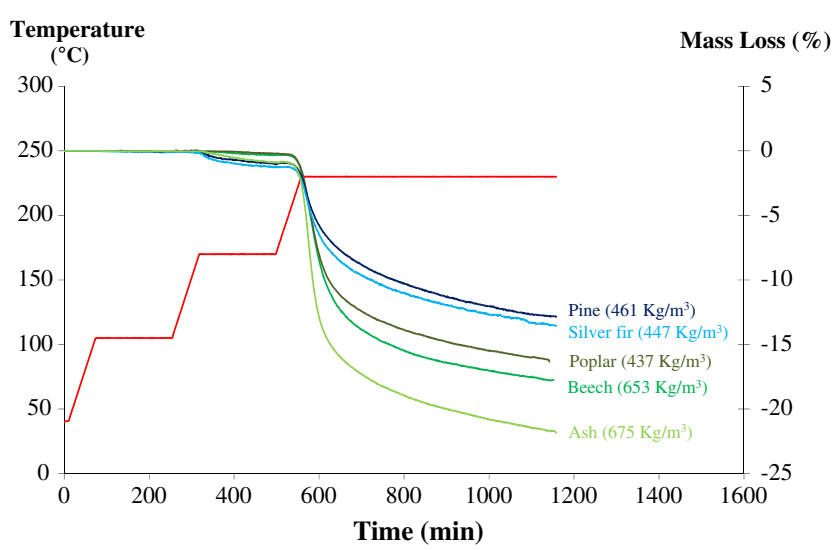

Fig. 1 Time course of mass loss (in \% of initial values) of wood from different species [Pine (Pinus sylvestris L.), Silver fir (Abies pectinate Lam.), Poplar (Populus nigra L.), Beech (Fagus sylvatica L.) and Ash (Fraxinus excelsior L.)] treated with a step wise increasing temperature up to $230{ }^{\circ} \mathrm{C}$ (in red). Initial wood density (kg dry mass per $\mathrm{m} 3$ ) is indicated for each species. The mass loss started at $160{ }^{\circ} \mathrm{C}$ but was particularly important at $230^{\circ} \mathrm{C}$. From Chaouch 2011, with permission

degradation for similar curing condition $\left(230^{\circ} \mathrm{C}\right)$ are strongly influenced by the nature of wood species. Hardwoods [beech (Fagus sylvatica L.), poplar (Populus nigra L.) and ash (Fraxinus excelsior L.)] have been shown to be more sensitive to thermal degradation than softwoods [pine (Pinus sylvestris L.) and silver fir (Abies pectinate Lam.)] as demonstrated by the higher mass losses recorded for a same treatment duration. Even if wood density cannot be totally excluded to justify these differences, wood species of lower densities being generally more resistant to thermal treatment than those of higher density. Wood chemical observed differences (Boonstra and Tjeerdsma 2006a). Hemicellulose composition of hardwoods can corroborate their higher susceptibility. Softwoods contain mainly arabinoglucoronoxylan and galactoglucomannan, while hardwoods contain a lower amount of glucomannan and mainly glucoroxylan. These hardwood xylan units are strongly acetylated, comparatively to softwood hemicelluloses (Fengel and Wegener 1989; Sjöström 1981). Moreover, an important amount of acetic acid is released during deacetylation of hemicellulose which catalyses depolymerisation of the less ordered carbohydrates as hemicelluloses and amorphous cellulose (Prinks et al. 2006). These differences were attributed to the differences of reactivity of the acetoxy and methoxy groups present as side chains in xylose units in the xylan containing hemicelluloses fraction.

Esteves et al. (2007) reported also a higher mass loss for eucalypt wood (Eucalyptus globulus Labill.) (hardwood) than for pine (Pinus pinaster L.) (softwood) under the same treatment conditions. Results have been confirmed by the identification of volatiles products formed during wood thermal degradation. With TD-GC-MS analyses, Candelier et al. (2011a) have shown that the high amount of acetic acid generated during thermal degradation of strongly acetylated glucoroxylan of hardwoods is associated to the formation of numerous degradation products resulting from lignin as well as hemicelluloses acid catalyzed degradations, such as furfural, hydroxymethylfurfural, guiaicol and vanillin. The quantities of these different components during thermal treatment are also linked to treatment intensity (Pétrissans et al. 2014). For a given temperature, the quantity of each degradation product increases progressively as the treatment duration increases (Candelier et al. 2013c). Zanuncio et al. (2014), using eucalyptus treated between 140 and $230{ }^{\circ} \mathrm{C}$ during 3 hours, found that mass loss varied from $0.33 \%\left(140{ }^{\circ} \mathrm{C}\right)$ to $0.63 \%$ $\left(170{ }^{\circ} \mathrm{C}\right)$, to $2.73 \%\left(200{ }^{\circ} \mathrm{C}\right)$ and to $10.73 \%\left(230{ }^{\circ} \mathrm{C}\right)$. Olarescu et al. (2014) studied the mass loss of lime wood (Tilia cordata Mill.) treated at 180 and $200{ }^{\circ} \mathrm{C}$, combined with four treatment durations; $1,2,3$ and 4 hours and showed that mass loss of heat treated wood increases according to temperature and treatment duration (Table 1).

Even if the strong influence of treatment temperature on the treatment intensity has been mentioned by several authors (Burmester 1970; Mazela et al. 2004; Boonstra et al. 2006b; Paul et al. 2006), according to the exponential kinetic of wood thermal degradation, the treatment duration has also an impact on treatment intensity as well as on mass loss kinetic (Bourgeois et al. 1989). Chaouch et al. (2010) found strong relations between mass loss (ML \%) and time of poplar (Populus nigra L.) thermal treatment, for several temperatures and treatment durations (Fig. 2).

Several studies have shown the influence of process atmosphere used on wood thermal degradation kinetic. Mazela et al. (2003) compared mass losses with heat treatment in air and in a water vapor atmosphere, using Pinus sylvestris $\mathrm{L}$. at $160{ }^{\circ} \mathrm{C}, 190{ }^{\circ} \mathrm{C}$ and $220^{\circ} \mathrm{C}$ during 6 and 24 hours. They verified that mass losses in the presence of air and of water vapor for 6 hours were very similar, but with 24 hours treatment the mass losses in air were higher, especially at $190{ }^{\circ} \mathrm{C}$ and $220^{\circ} \mathrm{C}$. Candelier et al. (2013c) found also differences of mass loss kinetic reaction of beech (Fagus sylvatica L.) heat treated wood between nitrogen and vacuum process, for

Table 1 Mass loss (ML, in \% of initial values) of heat-treated lime (Tilia cordata Mill.) wood according to treatment intensity. Mass Loss of heat treated wood increases according to temperature and treatment duration. From Olarescu et al. (2014), with permission

\begin{tabular}{ll}
\hline Heat treatment conditions & Mass Loss ML (in \% of initial values) \\
\hline $180{ }^{\circ} \mathrm{C} / 1 \mathrm{~h}$ & $1,3 \pm 0,2$ \\
$180{ }^{\circ} \mathrm{C} / 2 \mathrm{~h}$ & $1,7 \pm 0,1$ \\
$180{ }^{\circ} \mathrm{C} / 3 \mathrm{~h}$ & $2,1 \pm 0,2$ \\
$180{ }^{\circ} \mathrm{C} / 4 \mathrm{~h}$ & $2,4 \pm 0,3$ \\
$200{ }^{\circ} \mathrm{C} / 1 \mathrm{~h}$ & $4,3 \pm 1,1$ \\
$200{ }^{\circ} \mathrm{C} / 2 \mathrm{~h}$ & $5,0 \pm 0,4$ \\
$200{ }^{\circ} \mathrm{C} / 3 \mathrm{~h}$ & $6,7 \pm 0,4$ \\
$200{ }^{\circ} \mathrm{C} / 4 \mathrm{~h}$ & $9,3 \pm 0,7$ \\
\hline
\end{tabular}




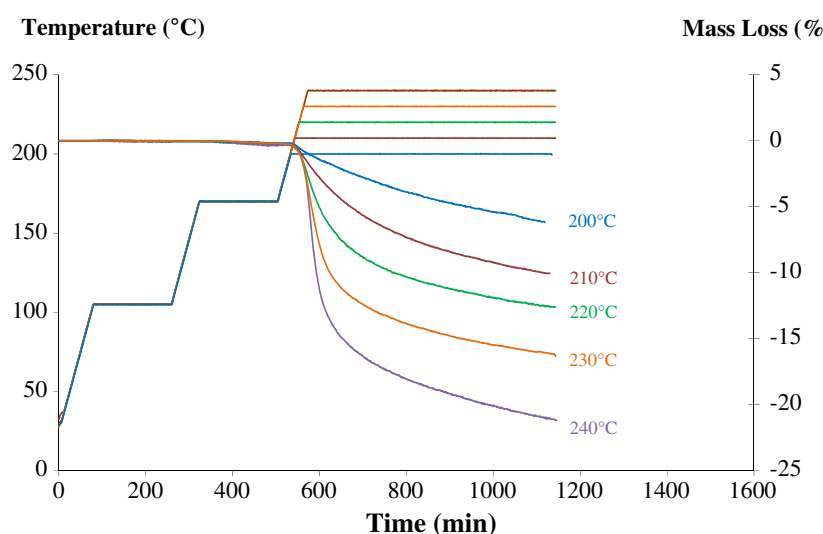

Fig. 2 Time course of mass loss (in \% of initial values) of wood from Poplar (Populus nigra L.) treated with a step wise increasing temperature up to different treatment temperatures from $200{ }^{\circ} \mathrm{C}$ to $240{ }^{\circ} \mathrm{C}$. The mass loss kinetic was impacted by the treatment temperature level. From Chaouch (2011), with permission

similar treatment intensity level. It appeared that vacuum utilization allows reducing the necessary drying time to stabilize wood mass (anhydrous) before thermal modification step limiting the overall treatment duration. Moreover heat treated wood under vacuum seemed to be less degraded than those treated under nitrogen. This difference may be easily explained by the effect of vacuum. Under vacuum, all volatile degradation products like acetic acid or furfural are removed progressively as soon as they are formed limiting the degradation of wood polysaccharides and the re-condensation of degradation products through thermal reticulation and crosslinking reactions (Candelier et al. 2013c). The influence of vacuum is also supported by the weakening of mechanical properties occurring during wood thermal modification (Candelier et al. 2014).

\section{Durability prediction by mass loss (ML \%) determination}

Several authors reported an increased resistance to decay for different wood species and several types of rots. The important degradation of hemicelluloses due to thermal treatment, which are generally considered as an important nutritive source as well as a prime key in the hygroscopic wood behavior for the development of wood rotting fungi, and modification of lignin network are also be involved to explain the ineffectiveness of fungal enzymatic attacks. These heat treated wood modifications are represented by mass loss (ML). Various authors compared the weight loss (WL) caused by fungal attack to the decrease in mass of wood by heat treatment (ML). For instance, Welzbacher et al. (2008) made a comparison between WL caused by Poria placenta (Poria placenta Coocke sensu J. Erikson (PP) [Fries, FPRL 280]) and ML, with heat treatment of Norway spruce (Picea abies
Karst.) performed in temperature range from $180^{\circ} \mathrm{C}$ to $240{ }^{\circ} \mathrm{C}$ and for durations comprised between 0,25 and 40 hours.

Figure 3 shows also that the impact of treatment temperature on ML was stronger than the impact of treatment time: for the same decrease in mass, higher temperatures led to lower WL by fungal decay (Poria placenta Coocke sensu J. Erikson (PP) [Fries, FPRL 280]) compared with lower temperatures. This concurs with results from Paul et al. (2006) and Mazela et al. (2004), who reported on limited improvement of resistance to fungal decay for heat treatment temperatures below $200{ }^{\circ} \mathrm{C}$. Indeed, two pieces of thermally modified wood may show the same ML due to heat treatment, but have completely different properties such as decay resistance, swelling shrinkage (Welzbacher et al. 2007) and mechanical properties (Candelier et al. 2011b).

Others studies verified WL-ML relationships with other type of processes, wood species and treatment intensity $\left(230^{\circ} \mathrm{C}\right)$. Chaouch et al. (2010) studied heat treatment (under nitrogen atmosphere) on five European wood species [beech (Fagus sylvatica L.), poplar (Populus nigra L.), ash (Fraxinus excelsior L.), pine (Pinus sylvestris L.) and silver fir (Abies pectinate $\mathrm{Lam}$.$) ] and proved a strong correlation between \mathrm{ML}$ $(5,10$ and $15 \%)$ and WL due to Coniophora puteana Karsten (CP) [Schumacher ex Fries, Bam Ebw. 15] (Fig. 4), Poria placenta Coocke sensu J. Erikson (PP) [Fries, FPRL 280], Coriolus versicolor Quélet (CV) [Linnaeus, CTB 863 A] and Gloeophyllum trabeum Murill (GT) [Persoon ex Fries, BAM Ebw. 109].

In another study conducted by Elaieb et al. (2015), 3 Tunisian softwood [Aleppo pine (Pinus halepensis Mill), Maritime Pine (Pinus pinaster Aiton) and Radiata pine (Pinus insignis D. Don)] and 1 Hardwood [Zeen oack (Quercus canariensis Willd)] species have been heat treated,

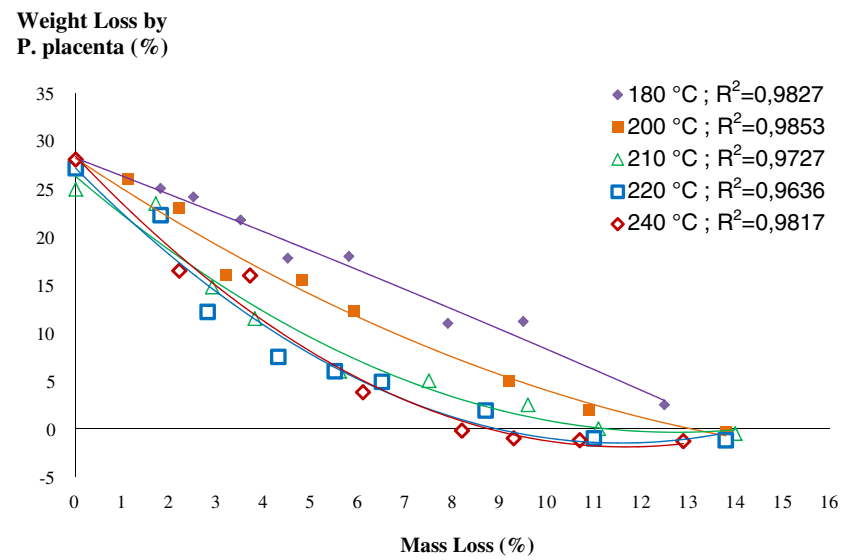

Fig. 3 Correlation between weight loss (WL \%) by Poria placenta (Poria placenta Coocke sensu J. Erikson (PP) [Fries, FPRL 280]) and decrease in mass (ML \%) for heat treatments on Norway spruce (Picea abies Karst.) performed with different treatment intensities. Treatment temperature $\left({ }^{\circ} \mathrm{C}\right)$ is indicated for each process. For the same decrease in mass (ML \%), higher temperatures led to lower WL. From Welzbacher et al. (2008), with permission 
Weight Loss by

P. placenta $(\%)$

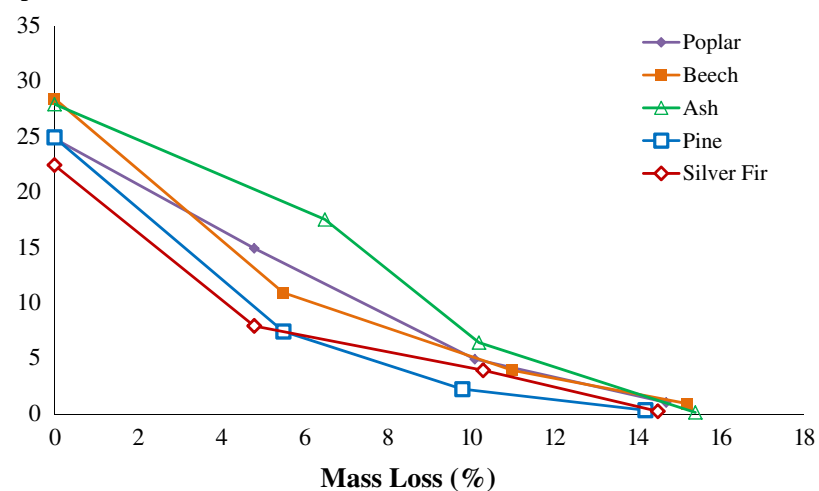

Fig. 4 Correlation between weight loss (WL \%) caused by Coniophora puteana (Coniophora puteana Karsten (CP) [Schumacher ex Fries, Bam Ebw. 15]) and Mass Loss due to wood thermal degradation (ML \%) for heat treatment on different European wood species [Pine (Pinus sylvestris L.), Silver fir (Abies pectinate Lam.), Poplar (Populus nigra L.), Beech (Fagus sylvatica L.) and Ash (Fraxinus excelsior L.)] performed at $230{ }^{\circ} \mathrm{C}$. ML was correlated with WL, for each wood species. From Chaouch et al. (2011), with permission

under vacuum process, at $230{ }^{\circ} \mathrm{C}$ during the required treatment duration to obtain wood Mass Loss (ML) of 8, 10 and $12 \%$. Strong correlations between ML and WL (due to Poria placenta Coocke sensu J. Erikson (PP) [Fries, FPRL 280]) have also been proven through this work. In most studies, an average mass loss (ML) of $12 \%$ confers to heat treated wood a durability class 3 according to the specifications of EN 350-1 (1994) standard (Welzbacher and Rapp 2002; Kamdem et al. 2002; Chaouch et al. 2010; Elaieb et al. 2015). In conclusion, treatment intensity which is characterized by ML has been demonstrated to be strongly correlated to each heat treated wood decay resistance. However, the introduction of a fast and accurate system for measuring this mass loss on an industrial scale is very difficult. Studies are currently conducted on the determination of others control parameters which could be also correlated with the treatment conditions and final heat treated wood quality such as decay resistance like spectroscopy analyses (Sandak et al. 2015; Popescu and Popescu 2013a), colour measurements (Kačíková et al. 2013), chemical composition determinations (Chaouch 2011), nondestructive mechanical tests (Hannouz et al. 2012), and industrial recording data (Candelier et al. 2015)

\section{Durability prediction by spectroscopic analyses}

Electron Spin Resonance (ESR) spectroscopy is a technical method based on the measurement of microwave resonance absorbance in the presence of an applied magnetics field. This microwave absorbance, recorded as its first derivative, is the ESR signal, which increases proportionally with the number of unpaired electrons present in the respective sample (Senesi and Senesi 2005). For thermally modified wood, an increase of the ESR signal intensity can be measured due to the formation of free radicals during the process (Viitaniemi et al. 2001). Therefore, ESR-spectroscopy is regarded as a potential method for the quality control of thermally modified wood (Viitaniemi et al. 2001; Willems et al. 2010). Recent investigations on ESR-Spectroscopy were done by Altgen et al. (2012), applied to several thermal modified wood species [ash (Fraxinus excelsior L.), beech (Fagus sylvatica L.) and spruce (Picea abies Mill.)] under different treatment intensities on laboratory as well as on industrial scale. Figure 5 shows correlations between ESR-relative intensities (ESR intensity sample / ESR intensity reference) and decay resistance (WL) (Gloeophyllum trabeum Murill (GT) [Persoon ex Fries, BAM Ebw. 109] and Trametes versicolor (L.) Lloyd [1920].

NIR-Spectroscopy method has been also investigated to predict wood thermal degradation intensity. Esteves and Pereira (2008) have found good correlations between predicted values issued from NIR analysis model and experimental values with mass loss (ML), MOE (Modulus of
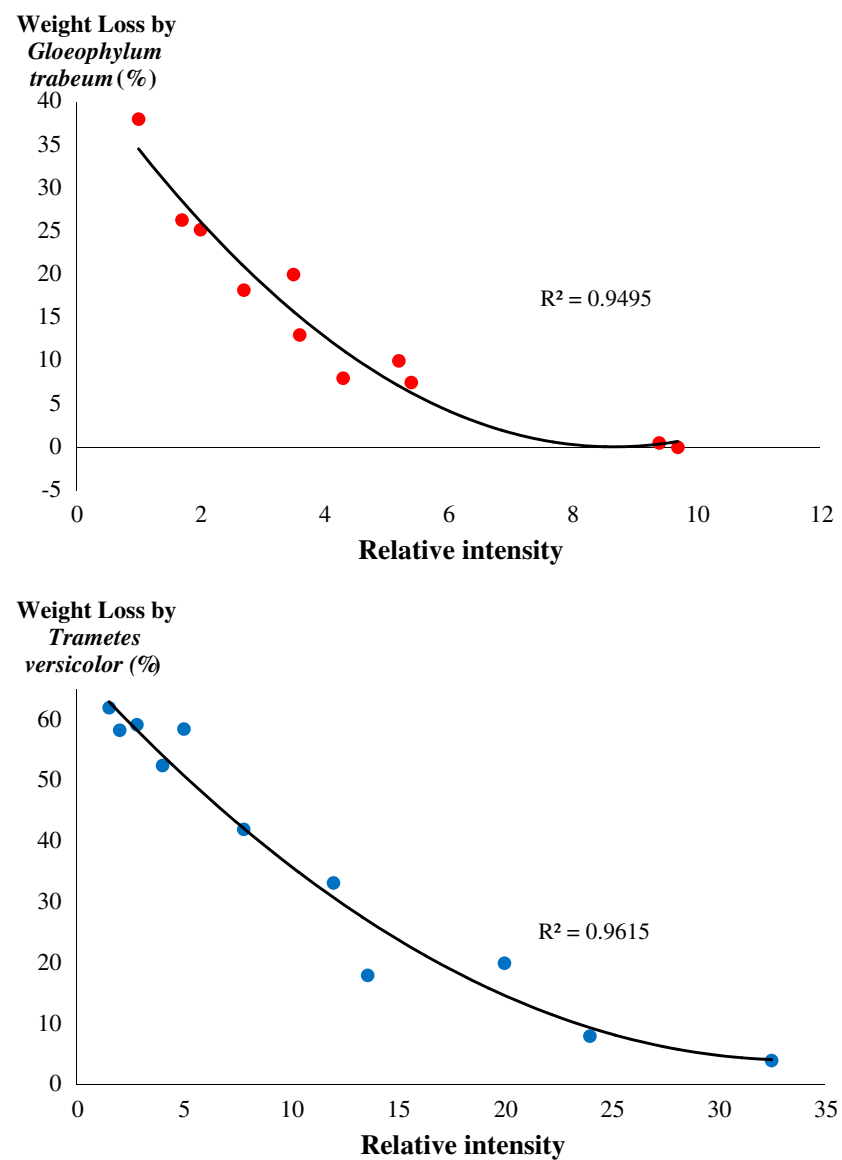

Fig. 5 Correlation between Weight Loss (WL \%) by Gloeophyllum trabeum (Gloeophyllum trabeum Murill [Persoon ex Fries, BAM Ebw. 109]) and Trametes versicolor (Trametes versicolor (L.) Lloyd [1920] and ESR- relative intensity. For the both fungal attacks, ESR- relative intensity was correlated with WL. From Altgen et al. (2012), with permission 
elasticity) and MOR (Modulus of Rupture ) in bending strength, equilibrium moisture content of wood and colour variation according to treatment intensities $\left(170-210{ }^{\circ} \mathrm{C} ; 2\right.$ $24 \mathrm{~h}$ ) and wood species (Pinus pinaster L. and Eucalyptus globulus Labill. ). NIR-Spectroscopy showed a good potential to be used for heat treated wood quality checking (Bächle et al. 2012), but no study has yet been conducted to compare directly heat treated durability with results issued to this spectrum analysis methods. However, NIRSpectroscopy (NIRS) as a rapid and non-destructive technique was successfully used for the final physical product properties quality control. Sandak et al. (2015) have recently shown that the NIRS analysis allows to evaluate the ML and EMC, with errors $0.9 \%$ and $0.36 \%$ respectively and with coefficients of determination higher than 0.94 . Therefore, both important parameters characterizing quality of Thermal Modified Wood (TMW) in vacuum conditions (EMC and ML) were predicted with high accuracy. Near Infrared Spectroscopy could be also used for decay resistance prediction and for optimization of the treatment procedure at the industrial scale and/or for on-line process control (Sandak et al. 2015). Indeed, Popescu and Popescu (2013a), 2013b) showed that the lime (Tilia cordata Mill.) wood samples treated at $140{ }^{\circ} \mathrm{C}$ and about $10 \%$ relative humidity for a period up to 504 hours, investigated by NIRS - second derivative - principal component analysis and 2D correlation analysis, indicates transformations in the chemical composition and structural changes induced by the degradation of wood components. The modifications and/or degradation of wood components occurring by hydrolysis, oxidation, and decarboxylation reactions could be evaluated by differences in the bands intensities or position from NIR and second derivative spectra.

Fourier Transform mid Infrared Spectroscopy (FT-IR) is another technical approach adapted to fast and nondestructive measurement of organic materials. The important advantages are accuracy, simplicity, and ability of performing very high number of tests without needs of any destruction to the material. Indeed, Li et al. (2015) found strong relationships between treatment intensity and main chemical components of stem heat treated teak (Tectona grandis L.F.) wood determined by FT-IR spectra and SD-IR (Second Derivative Infrared Spectroscopy) spectra analyses. FT-IR analysis method shows also good potential utilization to estimate heat treated wood durability, relating to heat treated wood chemical changes.

\section{Durability prediction by colour measurement}

Colour is a very important wood property for the final consumer and, in some cases is the key factor for the selection of a specific wood since for some end uses the aesthetic point of view is often prevailing. The darkening can be an important benefit of the heat treatment giving to the wood an aspect more valuable in some countries. This darker shade which is conferred to the wood by heat treatments is given by the production of colored degradation products from hemicelluloses (Sehistedt-Persson 2003; Sundqvist 2004) and from the extractives components (McDonald et al. 1997; Sundqvist and Morén 2002). Patzelt et al. (2003) suggested that colour evolution could be also used as a classification method of treated wood, because it has a significant correlation with treatment intensity (Viitaniemi et al. 1997; Mitsui et al. 2001, 2003), the mass loss (Bekhta and Niemz 2003; Esteves et al. 2008) and also the thermal process used. The classification of heat treated wood colour evolution can be valuable for one treatment methods but it cannot be used to compare the modification level of several modified woods issued from different industrial process. The CIELAB system is the most common method to estimate material colour. This $\mathrm{L}^{*} \mathrm{a}{ }^{*} \mathrm{~b}^{*}$ model measures the colour differences according to 3 axis: the $a$ axis extends from green $(-\mathrm{a})$ to red $(+\mathrm{a})$, the $b$ axis from blue $(-\mathrm{b})$ to yellow $(+b)$, and the brightness $(\mathrm{L})$ increases from black to white. The advantage of this system is that it is similar to human vision and very useful for camera or scanner imaging editing. Several studies have shown parabolic correlations between $\Delta \mathrm{E}$ $\left[\Delta \mathrm{E}=\left(\Delta \mathrm{L}^{2}+\Delta \mathrm{a}^{2}+\Delta \mathrm{b}^{2}\right)^{1 / 2}\right]$, representing color changes, after heat treatment, with the CIELAB system, and Mass Loss (ML) due wood thermal degradation (Gonzáles Peňa and Hale 2008; Tudorović et al. 2012). The wood browning after thermal treatment was also observed by Chen et al. (2012), and was caused primarily by changes in the polysaccharides. Bourgois et al. (1991) showed that both a decrease in $\Delta \mathrm{L} *$ and an increase in $\Delta \mathrm{E} *$ for wood subjected to heat treatments at $240-310{ }^{\circ} \mathrm{C}$ were caused by a decrease in the content of hemicelluloses, especially pentosans. The nature of colour change is complex as all essential wood components including the extractives may contribute to the change. Matsuo et al. (2010) have reported that the darker colour of heat-treated wood was attributed to the formation of degradation products from hemicelluloses, changes in extractives, and the formation of oxidation products such as quinones.

The CIELAB colour measurement was also mentioned as a possible approach for determinig treated wood quality by Brischke et al. (2007). Chemical, mechanical and colour traits of thermally modified wood showed close relationships, and therefore they can be used for their mutual predictions (Kačíková et al. 2013). Welzbacher et al. (2007) verified strong relations between color evolution, represented by luminescence change ( $\left.\mathrm{L}^{*}\right)$, of Norway spruce (Picea abies Karst.) heat treated, treatment intensity and the final wood material decay resistance (Fig. 6). However, Matsuo et al. (2010, 2011) have shown that treatment temperature has not a significant impact of heat treated hinoki (Chamaecyparis obtusa Endl.) wood colour evolution. These results indicate that it could be 
Weight Loss by

P. placenta $(\%)$

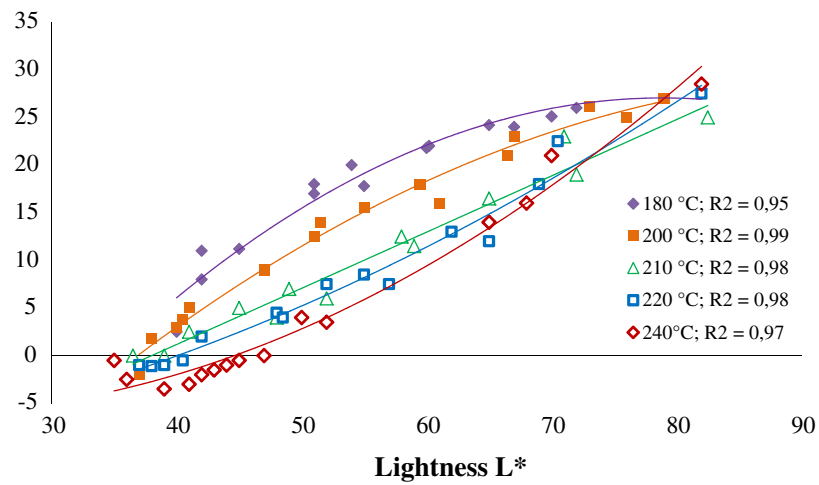

Fig. 6 Correlation between weight loss (WL \%) by Poria placenta (Poria placenta Coocke sensu J. Erikson (PP) [Fries, FPRL 280] and Lighteness $\mathrm{L}^{*}$, for different heat treatments on Norway spruce (Picea abies Karst.). Treatment temperature $\left({ }^{\circ} \mathrm{C}\right)$ is indicated for each process. For each treatment intensity, Lighteness $\mathrm{L}^{*}$ from colour measurement was correlated with WL. From Welzbacher et al. (2008), with permission

possible to predict treated wood mofidications and also its decay resistance, without taking into consideration the treatment temperature, for a same process used..

However, Johansson and Moren (2006) believe that colour is not suitable as predictor of heat treated wood quality because colour distribution through the thermally treated boards is not homogeneous. As a matter of fact, Esteves et al. (2008) have found that colour of the Pine wood (Pinus pinaster L.), heat-treated under steam pressure process at $190{ }^{\circ} \mathrm{C}$ during 6 hours, was not uniform because of the increased contrast between earlywood and latewood, and therefore the color of samples depended on the earlywood/latewood ratio from the sample surface. Moreover, in some cases, there was a formation of darker spots at the surface due to the exudation of some resins.

\section{Durability prediction by elemental composition $(\mathrm{O} / \mathrm{C})$ analysis}

Control and measurement of the mass loss of the material during the heat treatment process will allow predicting its finale decay resistance. This mass loss issued from wood thermal degradation is due to an importance rate of dehydration reactions occurring during the heat treatment, caused by degradation of amorphous polysaccharides (Fengel and Wegener 1989; Sivonen et al. 2002; Yildiz et al. 2006), jointly with the formation of carbonaceous materials within the wood structure leading to a strong decrease of wood Oxygen/Carbon ratio $(\mathrm{O} / \mathrm{C})$ (Inari et al. 2006, 2007). The behavior of carbon and oxygen contents has been evaluated through determination of wood's elemental composition by Inari et al. (2009). Since, several authors have investigated the way of $\mathrm{O} / \mathrm{C}$ molar ratio (Elaieb et al. 2015) and carbon oxidation state (Willems et al. 2013b) uses to predict heat treated wood decay resistance. Chaouch (2011) evaluated the correlations between the wood durability improvement of different softwood and hardwood species [beech (Fagus sylvatica L.), poplar (Populus nigra L.), ash (Fraxinus excelsior L.), pine (Pinus sylvestris L.) and silver fir (Abies pectinate Lam.)] and their respective $\mathrm{O} / \mathrm{C}$ ratios, on the basis of their ML due to thermal degradation. This author investigated the effect of thermal treatment temperatures $\left(180,200,210,220\right.$ and $\left.240{ }^{\circ} \mathrm{C}\right)$ and durations on the conferred durability to different European wood species. For the range of temperatures used, wood chemical composition appeared therefore to be a valuable marker of wood durability due to the strong correlations existing between treatment intensity and decay resistance towards (Coriolus versicolor Quélet (CV) [Linnaeus, CTB 863 A], Gloeophyllum trabeum Murill (GT) [Persoon ex Fries, BAM Ebw. 109], Coniophora puteana Karsten (CP) [Schumacher ex Fries, Bam Ebw. 15] and Poria placenta Coocke sensu J. Erikson (PP) [Fries, FPRL 280].

Evolution of lignin and holocellulose contents and their respective chemical structures or chemical compositions are directly correlated to Mass Losses (ML) due to thermal degradation reactions, which are also directly correlated to weight losses due to fungal attack (Mohareb et al. 2012). Even if mass losses of wood due to its thermal degradation reactions are not always readily available on industrial processes, it seems possible to easily establish calibration curves for given treatment conditions allowing further correlations between elemental composition, treatment intensity and wood decay resistance (Fig. 7). Elaieb et al. (2015) found similar results with thermal treatment performed under vacuum on Tunisian wood species (Aleppo pine [Pinus halepensis Mill.], Radiata pine [Pinus radiata D.Don.], Maritime pine [Pinus pinaster Aiton.] at

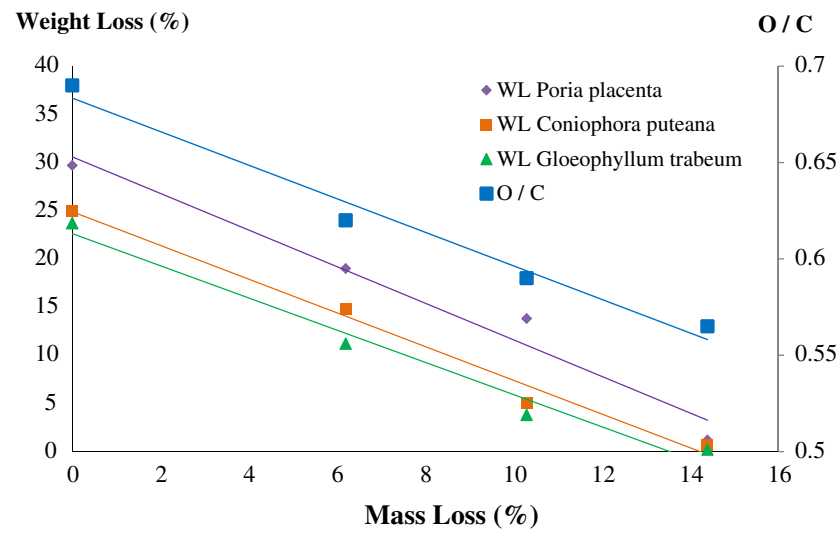

Fig. 7 Correlation between Weight Loss by different rots (WL) (Poria placenta Coocke sensu J. Erikson (PP) [Fries, FPRL 280], Coniophora puteana Karsten (CP) [Schumacher ex Fries, Bam Ebw. 15] and Gloeophyllum trabeum Murill (GT) [Persoon ex Fries, BAM Ebw. 109]), Mass Loss due to heat treatment (ML) and $\mathrm{O} / \mathrm{C}$ ratio, from poplar (Populus nigra L.) treated under nitrogen at $230{ }^{\circ} \mathrm{C}$. For each fungal attack, $\mathrm{ML}$ and $\mathrm{O} / \mathrm{C}$ ration were correlated to WL. From Chaouch (2011), with permission 
$230{ }^{\circ} \mathrm{C}$ and exposed to Poria placenta (Poria placenta

Coocke sensu J. Erikson (PP) [Fries, FPRL 280]) attacks.

\section{Durability prediction by tests carried out on industrial sites}

\subsection{Mechanical properties by nondestructive tests}

Most of thermal treatment processes are performed by convection and do not record the wood Mass Loss (ML) during the process (Borgeais 2012). Moreover, heat transfer by convection may give rise to unsatisfactory treatment homogeneity on the set of treated samples (Pétrissans et al. 2007). So, it is necessary to find and/or select some parameters, which could be easily used for industrial process, to estimate the ML (resulting from treatment intensity) and consequently predict the conferred decay resistance of heat treated wood.

Heat treated wood mechanical resistance, and particularly MOE and MOR in bending, decrease according to the treatment intensity (Kim et al. 1998; Bal 2014). Similar results have been reported by Jimenez et al. (2009). These authors studied also the decrease of mechanical properties and the improvement of decay resistance towards two fungi species; Fomes lividus (Kalchbr. ex Cooke) Sacc. (white rot) and Lenzites striata var. striata (Sw.) Fr. (brown rot), during heat treatment performed on Malapapaya (Polyscias nodosa (Blume) Seem.) wood under different treatment intensities (180-230 $\left.{ }^{\circ} \mathrm{C}, 30-120 \mathrm{~min}\right)$. Comparing the results of these two studies, it appears that MOR in bending destructive tests and WL (\%) issue from fungal attacks are correlated (Fig. 8). Even if MOE is constant whatever the process conditions and

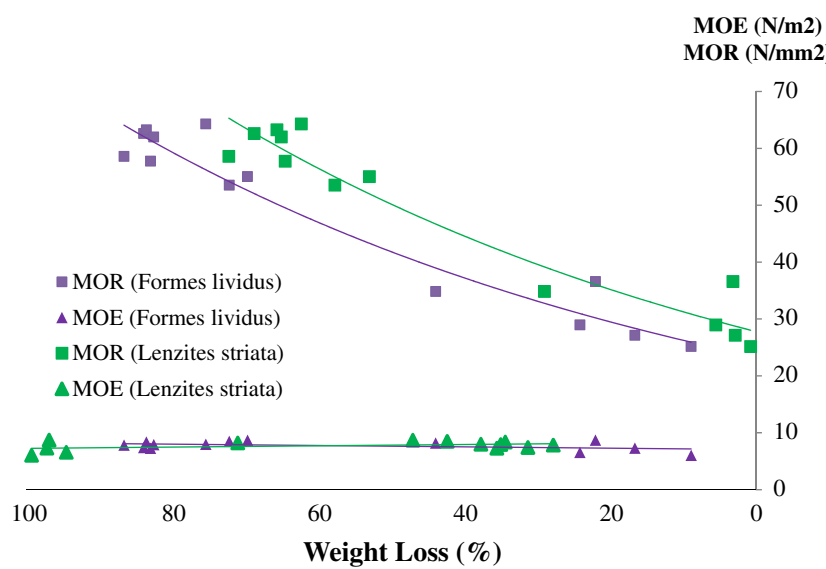

Fig. 8 Correlation between weight loss (WL\%) by white and browns rots [Fomes lividus (Kalchbr. ex Cooke) Sacc. and Lenzites striata var. striata (Sw.) Fr.], MOE and MOR in bending destructive tests, for heat treatments performed on Malapapaya [Polyscias nodosa (Blume) Seem] wood. Thermal process conditions used are the following: temperature ranged from 180 to $230^{\circ} \mathrm{C}$, and various durations comprised between 30 and $120 \mathrm{~min}$. Even if MOE is constant, MOR was correlated to WL. From Jimenez et al. (2011), with permission the conferred durability to the material, good correlations between MOR and WL (\%) have been highlighted.

It would therefore seem possible to predict final heat treated wood decay resistance by measuring some mechanical characteristics. However, some authors who have studied the durability prediction by mechanical properties determination have used destructive methods (Welzbacher et al. 2007; Elaieb et al. 2015). More recently, Hannouz et al. (2012) studied the possibility to use nondestructive mechanical tests, in order to estimate the mass loss and also the decay resistance of modified wood. By measuring MOE and MOR in bending before and after treatment, with BING ${ }^{\circledR}$ system analysis, Hannouz et al. (2012) found high correlations between mechanical properties and Mass Loss (ML). They established, mainly, a relation between ML (\%) derived/calculated from MOR measured with $\mathrm{BING}^{\circledR}$ method and real ML (\%) after thermal treatment of ash (Fraxinus excelsior L.) wood (Fig. 9). The BING $^{\circledR}$ analysis system is a method of mechanical properties characterization which is based on the study of the vibrations of wood material. It involves determining the linkage between the mechanical properties and the wooden material vibration behavior. The analysis of resonant frequency spectrum allows to obtain the elastic properties (longitudinal-MOE, transverse shear) and inelastic (internal friction associated with each resonant frequency) of any rigid material. The specimen is subjected to longitudinal or transverse vibrations whose recording and analysis lead to the identification of desired material characteristics. Such a nondestructive method could be also a good option to predict the final decay resistance of heat modified wood. However, such correlation does not operate on bending MOE values (Hannouz et al. 2012). It could be explained by the low moisture content of heat treated wood. Indeed, $\mathrm{BING}^{\circledR}$ method parameters have been determined for wood

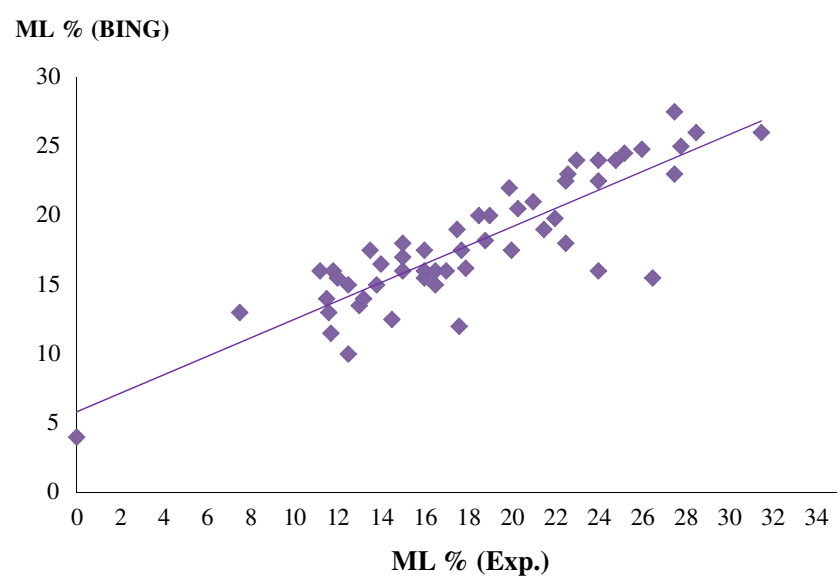

Fig. 9 Correlation between modelling ML (\%) and real ML (\%) from treated Ash (Fraxinus excelsior L.) wood under water steam pressure system. Treatment temperature used was $210{ }^{\circ} \mathrm{C}$ and different durations were performed to obtain various ML from 0 to 32 (in \% of initial values). Modelling ML (\%) and real ML (\%) were correlated but we observe a deviation probably due to a lower humidity of modified wood. From Hannouz et al. (2012), with permission 
moisture content of approximately $12 \%$, and it is difficult to obtain such moisture content for thermally modified wood.

\subsection{Utilization of wood temperature kinetic}

Another approach concerning modified wood decay resistance prediction consists in investigating the wood temperature kinetic during heat treatment (Candelier et al. 2015). The relative area, calculated from wood temperature curve, above $100{ }^{\circ} \mathrm{C}$ till heating temperature, has been proved to be an indicator of heat treatment intensity. Candelier et al. (2015) have shown, that for several wood species (Aleppo pine [Pinus halepensis Mill.], Radiata pine [Pinus radiata D.Don.], Maritime pine [Pinus pinaster Aiton.] and Zeen oak [Quercus canariensis Willd.]) and for different process conditions, this relative area seems to be a good indicator to estimate the final product quality and more particularly its durability improvement after a thermal modification (Fig. 10). Even if this study was conducted at a laboratory

a

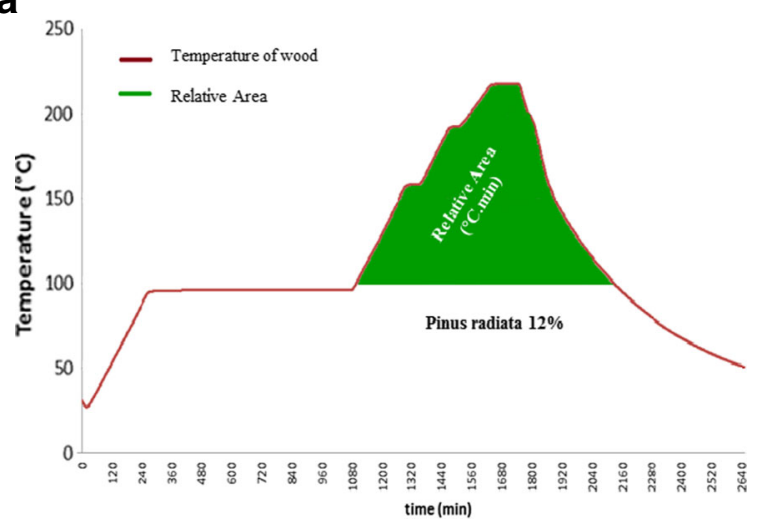

b

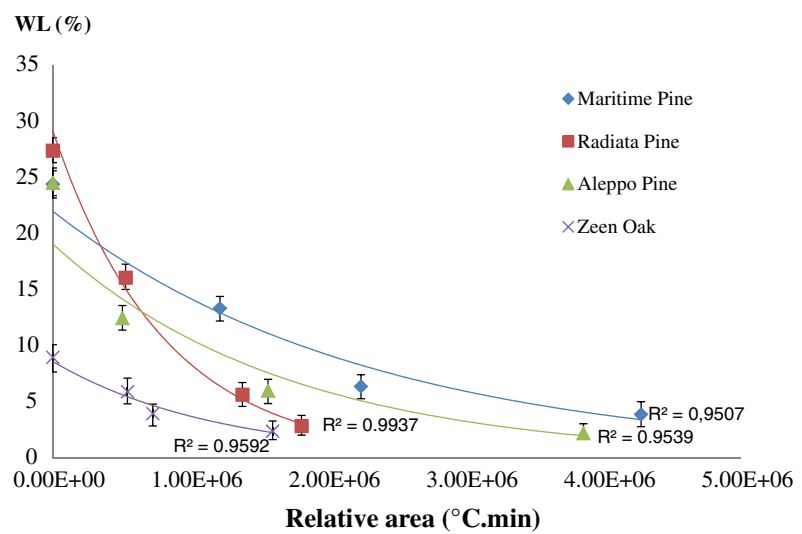

Fig. 10 (a) Relative area determination and (b) Prediction of Weight Losses due to Poria placenta (Poria placenta Coocke sensu J. Erikson (PP) [Fries, FPRL 280]) exposure by determination of relative Area, for different wood species (Aleppo pine [Pinus halepensis Mill.], Radiata pine [Pinus radiata D.Don.], Maritime pine [Pinus pinaster Aiton.] and Zeen oak [Quercus canariensis Willd.]. For each wood specie, relative area seems to be correlated to WL due to fungal exposure. From Candelier et al. (2015), with permission scale, relative area appears to be an easy and good potential industrial method to estimate the final commercialized products quality. The benefit of this method is to be efficiently achievable at industrial scale through heat treatment device which allow dynamic recording of wood temperature along the process. Even if the utilization of relative area from wood temperature kinetic gives to the producer a global quality estimation of heat treated wood issue from one treatment, this method not allow to obtain a quality control for each treated wood boards.

\section{Conclusion}

One of the most efficient indicators of the treatment efficiency is mass loss of wood due to its thermal degradation. However, the introduction of a fast and accurate system for measuring the mass loss and/or elemental composition on an industrial scale is very difficult. Nevertheless, an effective quality control measurement is overriding to estimate heat treated wood quality but also to optimize the process parameter. Colour tests allow to obtain a fast rating of heat treated wood durability, but this sort of measure is not precise and efficient enough taking into account wood variability and treatment heterogeneity. Spectroscopic analyses such as NIR or FT-IR are able to give information on the process extent (by estimating mass loss) and on the properties that are relevant for this wood modification and for the uses of heat treated wood (i.e. EMC, dimensional stability, and decay resistance), by an overall a single spectrum averaged over the solid surface of a heat treated wood sample. Therefore and given that the acquisition of NIR spectrum can be done quickly and easily on the solid surface of the samples using a fiber probe, and that spectral data processing can be done immediately afterwards, this is a methodology with an interesting potential for process and product quality control, once calibration and validation of the models have been made for the processed wood species. More recently, utilization of mechanical test on wood before and after thermal modification process (non-destructive methods, such as BING ${ }^{\circledR}$ ) could allow obtaining quickly and easily the acquisition of resonant frequency spectrum to estimate the heat treated wood properties. Although this method is widely and effectively used on industrial scale on native wood, this methodology needs calibration steps in order to be correctly used on modified wood material. Finally, use of relative area indicator issue from wood temperature kinetic is easily achievable at industrial scale through heat treatment device which allow dynamic recording of wood temperature along the process. Even if this indicator gives to the producer a global quality estimation of modified wood issue from one heat treated batch, this method not allow to obtain a quality control for each wood boards from this batch. This last method seems to be more efficient, easier and cheaper to consider it in 
industrial site, but it needs to be investigated for different wood thermal modification processes and on an industrial scale.

Open Access This article is distributed under the terms of the Creative Commons Attribution 4.0 International License (http:// creativecommons.org/licenses/by/4.0/), which permits unrestricted use, distribution, and reproduction in any medium, provided you give appropriate credit to the original author(s) and the source, provide a link to the Creative Commons license, and indicate if changes were made.

\section{References}

Allegretti O, Brunetti M, Cuccui I, Ferrari S, Nocetti M, Terziev N (2012) Thermovacuum modification of spruce (Picea abies karst.) and fir (Abies albamill.) wood. Bioresources 7:3656-3669

Altgen M, Welzbacher C, Humar M, Militz H (2012) ESR-spectroscopy as a potential method for the quality control of thermally modified wood. Proceedings of the 2nd Workshop Cost Action FP0904, Nancy, pp 132-133

Andersons B, Chirkova J, Andersone I, Irbe I (2012) Prediction of the properties of soft deciduous wood in thermal modification. Proceedings of the 2nd Workshop Cost Action FP0904, Nancy, pp 96-97

Bächle H, Zimmer B, Wegener G (2012) Classification of thermally treated wood by FT-NIR spectroscopy and SIMCA. Wood Sci Technol 46:1181-1192

Bal BC (2014) Some physical and mechanical properties of thermally modified juvenile and mature black pine wood. Eur J Wood Prod 72:61-66

Bekhta P, Niemz P (2003) Effect of high temperature on the change in color, dimensional stability and mechanical properties of spruce wood. Holzforschung 57:539-546

Boonstra M (2008) A two-stage thermal modification of wood, $\mathrm{PhD}$ Thesis in A plied Biological Sciences: Soil and Forest management. Henry Poincaré University, Nancy

Boonstra MJ, Tjeerdsma B, Pizzi A, Tekely P, Pendlebury J (1996) Chemical modification of Norway spruce and Scots pine: a $13 \mathrm{C}$ NMR CP-MAS study of the reactivity and reactions of polymeric wood components. Holzforschung 50:215-220

Boonstra MJ, Tjeerdsma B (2006) Chemical analysis of heat treated softwoods. Holz Roh Werkst 64:204-211

Boonstra MJ, Pizzi A, Zomers F, Ohlmeyer M, Paul W (2006) The effects of a two stage heat treatment process on the properties of particleboard. Holz Roh Werkst 64:157-164

Borgeais A (2012). The high temperature treatment of wood. The network timber professionals in Brittany [in French], Book (Abibois), 11 pages. Available at http://abibois.com/category/4-preservationet-entretien?download $=14$.

Bourgeois J, Bartholin MC, Guyonnet R (1989) Thermal treatment of wood: analysis of obtained product. Wood Sci Technol 23:303-310

Brischke C, Welzbacher C, Brandt K, Rapp A (2007) Quality control of thermally modified timber: interrelationship between heat treatment intensities and CIE L*a*b* color data on homogenized wood samples. Holzforschung 61:19-22

Burmester A (1970) Formbeständigkeit von Holz gegenüber Feuchtigkeit Grundlagen und Vergütungsverfahren. BAM Berichte Nr. 4.

Burmester A (1973) Investigation on the dimensionnal stabilization of woood. Bundesanstalt fûr Materialprûfung, Berlin-Dahlem, 50-56. Holz Roh Werkst 33:333-335
Burmester A (1975) Zur Dimensionsstabilisierung von holz. Holz Roh Werkst 33:333-335

Candelier K, Chaouch M, Dumarçay S, Petrissans A, Petrissans M, Gérardin P (2011a) Utilization of thermodesorption coupled to GC-MS to study stability of different wood species to thermodegradation. J Anal App Pyrol 92:376-383

Candelier K, Dumarçay S, Pétrissans A, Gérardin P, Pétrissans M (2011b) Mechanical properties of heat treated wood after thermodegradation under different treatment intensity. International Conference "Mechano-chemical transformations of wood during thermohydro-mechanical processes", 16-18 February 2011, Biel (Switzerland).

Candelier K, Dumarçay S, Petrissans A, Desharnais L, Petrissans M, Gérardin P (2013a) Comparison of chemical composition and decay durability of heat treated wood cured under different inert atmospheres: Nitrogen or vacuum. Polym Degrad Stab 98:677-681

Candelier K, Treu A, Dibdiakova J, Larnoy E, Dumarçay S, Pétrissans A, Gérardin P, Pétrissans M (2013b) Utilization of TG-DSC to study thermal stability of beech and silver fir. Document No. IRG/WP 1340628. The International Research Group on Wood Preservation, Sweden

Candelier K, Dumarçay S, Pétrissans A, Pétrissans M, Kamdem P, Gérardin P (2013c) Thermodesorption coupled to GC-MS to characterize volatiles formation kinetic during wood thermodegradation. J Anal App Pyrol 101:96-102

Candelier K, Dumarçay S, Pétrissans A, Gérardin P, Pétrissans M (2013d) Comparison of mechanical properties of heat treated beech woods cured under nitrogen or vacuum. Polym Degrad Stab 98:1762-1765

Candelier K, Dumarçay S, Pétrissans A, Gérardin P, Pétrissans M (2014) Advantage of vacuum versus nitrogen to achieve inert atmosphere during softwood thermal modification. Pro Ligno 10:10-17

Candelier K, Hannouz S, Elaieb MT, Collet R, Dumarçay S, Pétrissans A, Gérardin P, Pétrissans M (2015) Utilization of temperature kinetic as a method to predict treatment intensity and corresponding treated wood quality: durability and mechanical properties of thermally modified wood. Maderas-Ciencia Tecnologia 17:253-262

Chaouch M (2011) Effect of treatment intensity on the elemental composition and durability of heat-treated wood: development of a predictive marker of resistance to basidiomycete fungi [in French]. PhD Thesis. Université de lorraine, Nancy

Chaouch M, Pétrissans M, Pétrissans A, Gérardin P (2010) Use of wood elemental composition to predict heat treatment intensity and decay resistance of different softwood and hardwood species. Polym Degrad Stab 95:2255-2259

Chaouch M, Dumarçay S, Pétrissans A, Pétrissans M, Gérardin P (2013) Effect of heat treatment intensity on some conferred properties of different European softwood and hardwood species. Wood Sci Technol 47:663-673

Chen Y, Fan Y, Gao J, Stark NM (2012) The effect of heat treatment on the chemical and color change of black locust (Robinia pseudoacacia) wood flour. Bioresources 7:1157-1170

CRIQ (2003) Forest products issued from $2^{\text {nd }}$ transformation processes Wood heat treatment [in French]. Report to the ministère des Ressources naturelles, de la Faune et des Parcs (MRNFP) by the Centre de recherche industrielle du Québec (CRIQ).

Dilik T, Hiziroglu S (2012) Bonding strength of heat treated compressed Eastern red cedar wood. Mater Des 42:317-320

Elaieb MT, Candelier K, Pétrissans A, Dumarçay S, Gérardin P, Pétrissans M (2015) Heat treatment of Tunisian soft wood species: Effect on the durability, chemical modifications and mechanical properties. Maderas Ciencia Tecnologia 17:699-710

EN 113 (1996) Wood preservation products. Wood preservatives - Test method for determining the protective effectiveness against wood destroying basidiomycetes - Determination of the toxic values.

EN 335 (2013) Durability of wood and wood-based products - Use classes: definitions, application to solid wood and wood-based products. 
EN 350-1 (1994) Durability of wood and wood based products - Natural durability of solid wood - Part 1: Guide to principles of testing and classification of the natural durability of wood.

Esteves B, Pereira H (2008) Quality assessment of heat treated wood by NIR spectroscopy. Holz Roh Werkst 66:323-332

Esteves BM, Domingos IJ, Pereira HM (2007) Improvement of technological quality of eucalyptus wood by heat treatment in air at $170^{\circ} \mathrm{C}$ $200^{\circ} \mathrm{C}$. For Prod J57:47-52

Esteves B, Velez Marques A, Domingos I, Pereira H (2008) Heat-induced color changes of pine (Pinus pinaster) and eucalypt (Eucalyptus globulus) wood. Wood Sci Technol 42:369-384

Fengel D, Wegener G (1989) Wood chemistry ultrastructure relation. Walter de Gruyter.

Gieleber (1983) Dimensionsstabilierung von holz durch eine Feuchte/ Wârme/Druck-Behandlung. Holz Roh Werkst 41:87-94

Gonzáles Peňa M, Hale M (2008) Colour in thermally modified wood of beech, norway spruce and scots pine, Part 2: Properties predictions from colour changes. Holzforschung 63:394-401

Gunduz G, Aydemir D, Karakas G (2009) The effects of thermal treatment on the mechanical properties of wild Pear (Pyrus elaeagnifolia Pall.) wood and changes in physical properties. Mater Des 30:43914395

Hakkou M, Pétrissans M, Zoulalian A, Gérardin P (2005) Investigation of wood wettability changes during heat treatment on the basis of chemical analysis. Polym Degrad Stab 89:1-5

Hakkou M, Pétrissans M, Gérardin P, Zoulalian A (2006) Investigation of the reasons for fungal durability of heat-treated beech wood. Polym Degrad Stab 91:393-397

Hamada J, Petrissans A, Mothe F, Petrissans M, Gerardin P (2013) Analysis of the effects of the European oak natural variability on the modification of the density distribution and chemical composition during the heat treatment. Proceedings of the Joint focus workshop of COST Action FP1006 \& FP0904, 16-18 October, 2013 Rogla, Slovenia

Hannouz S, Collet R, Bléron L, Marchal R, Gérardin P (2012) Mechanical properties of heat treated French species wood. Proceedings of the 2nd Workshop Cost Action FP0904, Nancy, pp $940,72-74$

Hannouz S, Collet R, Buteaud JC, Bléron L, Candelier K (2015) Mechanical characterization of heat treated ash wood in relation with structural timber standards. Pro Ligno 11:3-10

Hietala S, Maunu S, Sundholm F, Jämsa S, Viitaniemi P (2002) Structure of thermally modified wood studied by liquid state NMR measurements. Holzforschung. 56:522-528

Hill CAS (2006) Wood modification: Chemical. Thermal and other processes, Wiley, Chichester

Hillis W (1984) High temperature and chemical effects on wood stability. Part 1. General consideration. Wood Sci Technol 18:281-293

Inari G, Pétrissans M, Lambert JL, Erhardt JJ, Gérardin P (2006) XPS characterization of wood chemical composition after heat treatment. Surf Interf Anal 38:1336-1342

Inari G, Petrissans M, Lambert J, Ehrhardt JJ, Gerardin P (2007) Chemical reactivity of heat-treated wood. Wood Sci Technol 41: $157-168$

Inari G, Pétrissans M, Pétrissans A, Gérardin P (2009) Elemental composition of wood as a potential marker to evaluate heat treatment intensity. Polym Degrad Stab 94:365-368

Jimenez JP, Acda MN, Razal RA, Madamba PS (2011) PhysicoMechanical Properties and Durability of Thermally Modified Malapapaya [Polyscias nodosa (Blume) Seem.] Wood. Philipp J Sci 140:13-23

Johansson D, Moren T (2006) The potential of color measurement for strength prediction of thermally treated wood. Holz Roh Werkst 64: $104-110$

Junga U, Militz H (2005) Particularities in agar block tests of some modified woods caused by different protection and decay resistance.
Proceedings of the 2nd European Conference on Wood Modification, Göttignen

Kačíková D, Kačíkb F, Čabalováb I, Ďurkovičc J (2013) Effects of thermal treatment on chemical, mechanical and colour traits in Norway spruce wood. Bioresour Technol 144:669-674

Kamdem DP, Pizzi A, Guyonnet R, Jermannaud A (1999) Durability of heat treated wood. Document No. IRG/WP 99-40145. The International Research Group on Wood Preservation, Rosenheim

Kamdem DP, Pizzi A, Jermannaud A (2002) Durability of heat-treated wood. Holz Roh Werkst 60:1-6

Kim G, Yun K, Kim J (1998) Effect of heat treatment on the decay resistance and the bending properties of radiate pine sapwood. Mater und Organismen 32:101-108

Kocaefe D, Poncsak S, Boluk Y (2008) Effect of thermal treatment on the chemical composition and mechanical properties of birch and aspen. Bioresources 3:517-537

Kollman A, Fengel D (1965) Changes in chemical composiyion of wood by heat treatment. Holz Roh Werkst 12:461-468

Kollman A, Schneider A (1963) On the sorption behavior of heat stabilized wood. Holz Roh Werkst 21:77-85

Korkut S, Korkut DS, Kocaefe D, Elustondo D, Bajraktari A, Çakıcıer N (2012) Effect of thermal modification on the properties of narrowleaved ash and chestnut. Ind CropProd 35:287-294

Kotilanen R (2000) Chemical changes in wood during heating at 150 $260^{\circ} \mathrm{C}$. Department of Chemistry. Finland, University of Jyväskylä, pp. 51

Li MY, Shi-Chao Cheng SC, Li D, Wang SN, Huang AM, Sun SQ (2015) Structural characterization of steam-heat treated Tectona grandis wood analyzed by FT-IR and 2D-IR correlation spectroscopy. Chin Chem Lett 26:221-225

Matsuo M, Yokoyama M, Umemura K, Gril J, Yano H, Kawai S (2010) Color changes in wood during heating: kinetic analysis by applying time-temperature superposition method. Appl Phys A 99:47-52

Matsuo M, Yokoyama M, Umemura K, Sugiyama J, Kawai S, Gril J, Kubodera S, Mitsutani T, Ozaki H, Sakamoto M, Imamura M (2011) Aging of wood: Analysis of color changes during natural aging and heat treatment. Holzforschung 65:361-368

Mazela B, Zakrzewski R, Grzeskowiak W, Cofta G, Bartkowiak M (2003) Preliminary research on the biological resistance of thermally modified wood. Proceedings of the 1st European Conference on Wood Modification, Ghent

Mazela B, Zakrzewski R, Grzeskowiak W, Cofta G, Bartkowiak M (2004) Resistance of thermally modified wood to basidiomycetes. ; EJPAU, Wood Technology, 7(1). Avaible at http://www.ejpau. media.pl.

McDonald A, Fernandez M, Kreber B (1997) Chemical and UV-VIS spectroscopic study on kiln brown stain formation in Radiata pine. Proceedings of the $9^{\text {th }}$ international symposium of wood and pulping chemistry, Montreal, 70, 1-5.

Militz H (2002) Heat treatment of wood: European Processes and their background. Document No. IRG/WP 02-40241. The International Research Group on Wood Preservation, Cardiff, Wales

Mitsui K, Takada H, Sugiyama M, Hasegawa R (2001) Changes in the properties of light-irradiated wood with heat treatment: Part 1 Effect of treatment conditions on the change in colour. Holzforschung 55: $601-605$

Mitsui K, Murata A, Kohara M, Tsuchikawa S (2003) Color modification of wood by light-irradiation and heat treatment. Proceedings of the 1st European conference on wood modification, Ghent

Mohareb A, Sirmah P, Pétrissans M, Gérardin P (2012) Effect of heat treatment intensity on wood chemical composition and decay durability of Pinus patula. Eur J Wood Prod 70:519-524

Nguila Inari G, Pétrissans M, Pétrissans A, Gérardin P. (2009). Elemental composition of wood as a potential marker to evaluate heat treatment intensity. Polym Degrad Stab 94:365-368 
Nuopponen M., Vuorinen T., Jamsa S., Viitaniemi P (2004) Thermal modifications in softwood studied by FT-IR and UV resonance raman spectroscopie. J Wood Chem Technol 24(1):13-26

Olarescu MC, Campean M, Ispas M, Cosereanu C (2014) Effect of thermal treatment on some properties of lime wood. Eur J Wood Prod 72:559-562

Patzelt M, Emsenhuber G, Stingl R (2003) Color measurement as means of quality control of thermally treated wood. Procedings of the 1 st European Conference on Wood Modification, Ghent

Paul W, Ohlmeyer M, Leithoff H (2006) Thermal modification of OSBstrands by a one-step heat pretreatment - Influence of temperature on weight loss, hygroscopicity and improved resistance. Holz Roh Werkst 65:57-63

Pétrissans M, Pétrissans A, Gérardin P (2007) Check the durability of heat-treated beech wood [in French]. Tracés, Bulletin technique Technologie du bois de la Suisse Romande 17:12-16

Pétrissans M, Pétrissans A, Gérardin P (2013) Pore size diameter, shrinkage and specific gravity evolution during the heat treatment of wood. Journal of Innovation In Forest Industry And Engineering Design.

Pétrissans A, Younsi R, Chaouch M, Gérardin P, Pétrissans M (2014) Wood, thermodegradation: experimental analysis and modeling of mass loss kinetics. Maderas Ciencia Tecnologia 16:133-148

Popescu CM, Popescu MC (2013) A near infrared spectroscopic study of the structural modifications of lime (Tilia cordata Mill.) wood during hydro-thermal treatment. Spectrochim Acta Mol Biomol Spectrosc 115:227-233

Popescu MC, Froidevaux J, Navi P, Popescu CM (2013) Structural modifications of Tilia cordata wood during heat treatment investigated by FT-IR and 2D IR correlation spectroscopy. J Mol Struct 1033: 176-186

Prinks MJ, Ptasinski KJ, Jansen FJJG (2006) Torrefection of wood, part 2. Analysis of products J Anal App Pyrol 77:35-40

Rapp A (2001) Review on heat treatments of wood, COST ACTION E22- Environmental optimisation of wood protection. Proceedings of Special Seminar in Antibes, França

Rep G, Pohleven F, Bucar B (2004) Charateristics of thermally modified wood in vacuum. Document No. IRG/WP 04-40287. The International Research Group on Wood Preservation, Ljubljana

Rusche H (1973a) Thermal degradation of wood at temperature up to $200^{\circ} \mathrm{C}$ : Part I. Holz Roh Werkst 31:273-281

Rusche H (1973b) Thermal degradation of wood at temperature up to $200^{\circ} \mathrm{C}$ : Part II. Holz Roh Werkst 31:307-312

Sandak A, Sandak J, Allegrtti O (2015) Quality control of vacuum thermally modified wood with near infrared spectroscopy. Vacuum 114: 44- 48

Seborg R, Tarkow H, Stamm A (1953) Effect of heat upon the dimensional stabilization of wood. J For Prod Soc 3(9): 59-67. SehistedtPersson (2003) Colour responses to heat treatment of extractives and sap from pine and spruce. Proceedings of the 8th International IUFRO wood drying conference, Brasov, pp 459-464

Sehistedt-Persson M (2003) Colour responses to heat treatment of extractives and sap from pine and spruce. Proceedings of the 8th IUFRO Wood Drying Conference European, Brasov

Senesi N and Senesi GS (2005) Electron-spin resonance spectroscopy. Encyclopedia of soils in the environment. Daniel, H. Oxford, Elsevier, 426-437.

Sivonen H, Maunu SL, Sundholm F, Jämsä S, Viitaniemi P (2002) Magnetic resonance studies of thermally modified wood. Holzforschung 56:648-654

Sjöström E (1981) Wood polysaccharides, in Wood chemistry. Fundamentals and applications. Academic press. Chapter 3:49-67

Stamm A, Hansen L (1937) Minimizing wood shrinkage and swelling: effect of heating in various gases. Ind Eng Chem 29:831-833

Stamm A, Burr H, Kline A (1946) Stayb-wood-A heat stabilized wood. Ind Eng Chem 38:630-634
Sundqvist B (2004) Color changes and acid formation in wood during heating. PhD Thesis. Lulea, University of Technology, Sweden

Sundqvist B, Morén T (2002) The influence of wood polymers and extractives on wood colour induced by hydrothermal treatment. Holz Roh Werkst 60:375-376

Surini T, Charrier F, Malvestio J, Charrier B, Moubarik A, Castéra P (2012) Physical properties and termite durability of maritime pine Pinus pinaster Ait., heat-treated under vacuum pressure. Wood Sci Technol 46: 487-501.

Šušteršic Ž, Mohareb A, Chaouch M, Pétrissans M, Petrič M, Gérardin P (2010) Prediction of decay resistance of heat treated wood on the basis of its elemental composition. Polym Degrad Stab 95:94-97

Tenorio C, Moya R (2013) Thermogravimetric characteristics, its relation with extractives and chemical properties and combustion characteristics of ten fast-growth species in Costa Rica. Thermochim Acta 563:12-21

Tiemann H (1920) Effects of different methods of drying on the strength and hygroscopicity of wood. 3er Ed. "The Kiln drying of lumber", Chap 11, J.P.Lippincott Co.

Tjeerdsma BF, Militz H (2005) Chemical changes in hydrothermal treated wood: FTIR analysis of combined hydrothermal and dry heat treated wood. Holz Roh Werkst 63:102-111

Tjeerdsma BF, Boonstra M, Pizzi A, Tekely P, Militz H (1998) Characterisation of the thermally modified wood: molecular reasons for wood performance improvement. Holz Roh Werkst 56:149-153

Tjeerdsma BF, Stevens M, Militz H (2000) Durability aspects of hydrothermal treated wood. Document No. IRG/WP00-40160. The International Research Group on Wood Preservation, Kona Surf, Hawaii

Tudorović N, Popović Z, Milić G, Popadić R (2012) Estimation of heat treated wood properties by color change. Bioressources 7:799-815

Viitaniemi P, Jämsä S, Viitanen H (1997) Method for improving biodegradation resistance and dimensional stability of cellulosic products. United States Patent No. 5678324 (US005678324).

Viitaniemi P, Jämsä S, Sundholm F (2001) Method of determining the degree of modification of heat modified wood products. WO/2001/ 053812, Search International and National Patent Collections.

Welzbacher CR, Rapp OA (2002) Comparison of thermally modified wood originating from four industrial scale process - durability. Document No. IRG/WP 02-40229. The International Research Group on Wood Preservation, Cardiff, Wales

Welzbacher CR, Brischke C, Rapp OA (2007) Influence of treatment temperature and duration on selected biological, mechanical, physical and optical properties of thermally modified timber. Wood Mater Sci Eng 2:66-76

Welzbacher CR, Jazayeri L, Brischke C, Rapp AO (2008) Increased resistance of thermally modified Norway spruce timber (TMT) against brown rot decay by Oligoporus placenta - Study on the mode of protective action. Wood Research 53:13-26

Willems W (2013) Methods of TMT quality control. Proceedings of the Cost Action FP 0904 :"Potential of THM Wood in Industrial Production", May 16-17 2013, Dresden

Willems W, Tausch A, Militz H (2010) Direct estimation of the durability of high-pressure steam modified wood by esr-spectroscopy. Document No. IRG/WP 10-40508. The International Research Group on Wood Preservation, Biarritz

Willems W, Gérardin P, Militz H (2013) The average carbon oxidation state of thermally modified wood as a marker for its decay resistance against Basidiomycetes. Polym Degrad Stab 98:2140-2145

Yildiz S, Gezer D, Yildiz U (2006) Mechanical and chemical behaviour of spruce wood modified by heat. Build Environ 41:1762-1766

Zanuncio AJV, Motta JP, Silveira TA, De Sa FE, Trugilho PF (2014) Physical and colorimetric changes in Eucalyptus grandis wood after heat treatment. Bioresources 9:293-302 